\title{
Twenty Years of Girls into Computing Days: Has It Been Worth the Effort?
}

\author{
Annemieke Craig \\ Deakin University, Melbourne, Victoria, Australia \\ acraig@deakin.edu.au \\ Catherine Lang \\ Swinburne University of Technology, Melbourne, \\ Victoria, Australia \\ clang@swin.edu.au \\ Julie Fisher \\ Monash University, Melbourne, Victoria, Australia \\ julie.fisher@infotech.monash.edu.au

\section{Executive Summary}

The first documented day-long program to encourage girls to consider computing as a career was held in 1987 in the U.K. Over the last 20 years these one-day events, labeled Girls into Computing days, have been conducted by academics and professionals to foster female-student interest in information technology (IT) degrees and careers. This paper charts the growth and popularity of these types of events internationally and questions their effectiveness. The format of Girls in Computing days varies from giving students hands-on experiences with technology to exposure to women in the industry through seminars and presentations. They are mostly aimed at girls in the 12-16 year old age bracket. The underlying assumption of these events is that female students are not choosing IT degrees and careers because of a limited awareness of what an IT degree and career involves. The absence of any longitudinal evaluation on the success of Girls into Computing events is a glaring oversight. Success of previous events conducted in the UK, USA, and Australia has been evaluated mainly through pre-event and post-event attitudinal type surveying of students. These have all been positive, but any long-term attitudinal change has not been measured and some researchers suggest that the effects of Girls in Computing days have been negligible, a suggestion supported by a continued decline in female IT higher education enrolment statistics in all these countries.

In Australia there has been a plethora of these types of events, some catering to over 1000 girls a

Material published as part of this publication, either on-line or in print, is copyrighted by the Informing Science Institute. Permission to make digital or paper copy of part or all of these works for personal or classroom use is granted without fee provided that the copies are not made or distributed for profit or commercial advantage AND that copies 1) bear this notice in full and 2) give the full citation on the first page. It is permissible to abstract these works so long as credit is given. To copy in all other cases or to republish or to post on a server or to redistribute to lists requires specific permission and payment of a fee. Contact Publisher@,InformingScience.org to request redistribution permission. day, some smaller and more personalized. Information about these events is presented in tabular form in the paper. This is followed by a questioning of how to measure success or, indeed, if it can be measured at all. The researchers ask if the amount of time and effort, presented as costs and benefits, is worth it, given that there has been no change in the steady decline of women in IT. 
The paradox of how to measure the effectiveness of an event that attracts large international sponsorship and is presented to over 1000 girls a day over a smaller, localized, and personalized event with limited sponsorship is posed as a question that is yet to be answered. The sustainability of energy of the volunteers who run these events, women in IT, not the dominant gender of the discipline, is also presented as a paradox. This gender paradox complicates the evaluation of whether size matters in the construction of events to increase awareness around IT careers.

A strategic evaluation of the measurement of success of Girls in Computing days needs to be adopted. There is no quick solution, and longitudinal tracking of student attendees and their future degree and career choices is complicated by privacy and funding issues. There is one example in the paper of an Australian follow-up proposal that is due next year. A survey of students who participated in a 2006 event is planned by the authors for 2009. It is concluded that we cannot afford to dismiss these days outright. We cannot conclude whether large events are better than smaller events until we have more robust data. Finally we must keep encouraging the dominant gender of the discipline to take a greater interest in the ownership of this issue for sake of the depth of diversity and creativity in the IT profession.

Keywords: Gender, female, computing, under-representation, recruitment

\section{Introduction}

In 1991, 27.6\% of the students enrolled in Australian tertiary computing degrees were female (Gibson \& Hartnett, 1993). At this time the Federal Government indicated that raising the number of women in such non-traditional degrees to $40 \%$ was a priority (Byrne $\&$ Staehr, 2005). In 1992, a growing concern among a small group of academics in Tasmania about the lack of girls in their computing degrees prompted the inaugural Australian Conference on Women in Computing. The opening address at the conference was presented by the then Minister The Hon. Wendy Fatin, Tasmanian MP, and Minister assisting the Prime Minister for the Status of Women, who expressed concern that, although women represented half the population and brains of the nation, there was an under representation of women in computing and science degrees at both undergraduate and postgraduate levels. She spoke of strategies to reach the targeted $40 \%$ female enrolment in computing and highlighted computing days and computing camps for fostering female secondary school girls' interest in degrees, as well as academic support groups and role-modeling for tertiary computing students (Fisher, Perry, Scollary, Singh, Watson, \& Vale, 1992). Since then many Australian Universities have developed strategies to address the decline of women enrolling in information technology (IT) degrees. Hosting a day where girls come and interact with technology has been a common approach and is often called a Girls in Computing day.

The underlying assumption of these events was that girls were not choosing IT as a career option in the same proportion as boys because they were not aware of computing as a career path. These days were a chance to address this lack of awareness and introduce girls to IT as a rewarding and exciting career path. Hands-on interaction was purported to offer a positive experience that would encourage the girls to go back to their schools and pursue further interaction with IT and develop a stronger self-efficacy with computing applications. A simple Google search confirms the continuing interest in running such events. For example, in 2007 St. Bonaventure University conducted a Girls' Day in New York (their sixth such event) and the University of Toronto conducted GR8 Designs for GR8 Girls to introduce Grade 8 girls to computer science, and on May 3, 2008, in Maryland, UMBC's Center for Women and Information Technology held its sixth annual day to expose girls in grades 6 to 8 to IT related careers,.

Career-decision making literature provides the theoretical underpinning for these programs. In the USA this body of literature focuses on choosing colleges and majors (Hossler, Schmit, \& Vesper, 1999). These researchers concluded that "gathering and processing information in a so- 
cial setting is an essential part of decision-making" (p.151). In the UK researchers questioned the assumption that it is the individual's freedom to choose. In reality, degree and career choices are influenced by external factors and, in some cases, fortuitous circumstance, called "happenstance" (Hodkinson \& Sparkes, 1997). This aspect of Hodkinson and Sparkes' theory is particularly relevant to girls and IT. It emphases a fluid and non-linear decision-making process where the students are influenced by events or people they meet at turning-points in their life. It is anticipated that these opportunities are provided through the many Girls in Computing days.

It is therefore appropriate, given the sustained interest and effort in developing and presenting such day-long programmes for girls, to examine the extent to which they are effective. This paper uses an Australian focus, charting how one-day programs to encourage girls to study IT have developed over time. It describes the outcomes of such events in general terms, highlighting the difficulty of evaluation. It concludes with a reflection on the effectiveness of large-scale girls in computing days as opposed to smaller more personal programs, raising some questions around the absence of longitudinal data on the effectiveness of these programs.

\section{Girls and Computing Days - International Experience}

The problem of the decline of women in IT is not unique to Australia. There are numerous overseas studies reporting similar declines and describing strategies to address the issue (see for example Doerschuk, Liu, \& Mann, 2007; Margolis \& Fisher, 2002; Sivilotti \& Demirbas, 2003).

An account of the 1987 Women into Computing Workshop conducted at the University of Glasgow was given at the first National Conference on Women in Computing in 1988 in England. The authors reported that a workshop for 100 girls was originally planned; however, a second workshop was run on the subsequent day for another 200 girls because over 2000 girls had applied to attend the initial workshop. These girls were in their third year of secondary education (14 to 15 years old). To give each girl "the opportunity to try using a personal computer" practical sessions were organized using Exper-Logo and MacPaint, plus a demonstration of HyperCard (Watt, 1988, p. 112). Six female speakers also presented talks to the girls to "convince them that computing was a real option and to provide them with role models" (Watt, 1988, p.112). The workshops were described as "a great success" and "a very worthwhile experience" (Watt, 1988, p. 114) and Siann and Callaghan (2001, p.88) suggested that these workshops were "held up as exemplars to other universities." A panel session at a Computer Science Education conference described a one day workshop in the UK for 13 year old girls that had then been run for nine years (Moses et al., 1994). The workshops were designed to give girls hands-on experience. However, no information on the outcomes has been reported.

Virginia Tech (2007) has run a Women in Computing Day for middle school girls in the United States for 10 years. There is, however, limited information on how these days have been evaluated, if at all, or what outcomes have been achieved from 10 years worth of programmes run by Virginia Tech. Sivilotti and Demirbas (2003) describe a workshop organized by Ohio State University in 2002 to encourage 12 and 13-year-old girls to study computer science. The girls were asked to evaluate each of the activities they participated in, how much they knew about computer science before undertaking the activity, and if computer science was more interesting to them at the end of the day. The results indicated that prior to the activities girls did not have much knowledge of computer science; they were more interested having completed the activities and rated the activities very highly. Doerschuk et al. (2007), from Lamar University in Texas, reported on a one-day camp for middle school girls. To assess the effectiveness of the one day camp, girls were asked to complete a questionnaire before and after the camp reporting their level of interest in computing and related activities and their response to the camp. The girls reported that they enjoyed the camp and their interest in computing and computing related activities improved. 
This international research suggests that one-day girls in computing programmes have been conducted for many years. Success was generally measured by assessing a change in attitude to computers over the course of one day and the extent to which the girls enjoyed the day and the activities. There appears to have been no longitudinal studies on whether there have been any long-term attitudinal change towards IT degrees or careers, though Pearce (1998, p.8 as cited by Siann \& Callaghan, 2001) suggests that the impact on increasing the number of girls into computer science degrees through these activities "has been negligible." This could certainly be the conclusion drawn if declining enrolment in IT statistics were all that is considered. Measurement of success is problematic and will be discussed in more detail later in this paper.

\section{Australian Girls in Computing Days}

The availability of equity funding for projects, as a result of the Government's target of $40 \%$ female participation, inspired a flurry of intervention strategies around Australia (Craig, Fisher, Scollary, \& Singh, 1998). A number of independent Girls in Computing days were held, mostly conducted by University staff. Some were a 'once only' venture, though activities at a number of universities persisted over several years. The early programmes tended to be small, organized and run by one university and often with limited funding. Since 2000 we have seen much larger programmes where industry and universities have come together on a state-wide basis, with significantly more funding to run girls in computing days. Some examples of these early programmes, small and large, are provided below and are grouped in chronological order.

\section{$1992-2000$}

A paper describing a Girls into Technology Day, conducted in 1991 for 66 girls in Year 10 (15-16 years of age) was presented at the 1992 Australian Women in Computing conference (Vale, 1992). The day consisted of practical sessions with MacPaint, Storyboard, and Spreadsheets, as well as discussions about IT careers. Students' evaluations indicated that they perceived the program to be worthwhile and expressed a very high level of interest in studying IT at university in the future. Without a pre-survey, however, it was not possible to say whether the girls had been influenced to study computing in the future by the one-day program. Vale recommended that future programmes include both a pre and post event survey, the use of only the latest software, and a greater selection of speakers from industry as role models.

Similar events were conducted during the 1990s by a number of Universities throughout the country. Victoria University, for example, ran such days annually for six years from 1992 to 1997. Each day was aimed at approximately 70-80 girls aged 14-16 from neighboring secondary schools. In each instance the girls were given hands-on experience with a series of activities, as well as up-to-date information about computing careers. The primary aim of the days was for the girls to be able "to see the computing field as more than programming or word processing" and that this then would help them to consider the possibility of a career in computing (Craig et al., 1998, p. 10). The Victoria University program was evaluated with pre and post surveys, which indicated that in the short term the days were a success. The days were enjoyed by the girls who considered them thought-provoking and interesting. A shift in the girls' views over the day also occurred with data showing that after the day more girls were aware that professional computing people did not spend most of their time just working alone and programming (Craig \& Fisher, 1996, p. 15). Consequently it was concluded that the activities had clearly given the girls a different picture of what work in the computing field might entail.

\section{Go Girl Go for IT - 2000 to 2006}

The industry-based group WIT (Women in Information Technology Inc.) in the state of Queensland decided that something on a grander scale had to be done as the participation of women in 
IT continued to decline. In 2000 the group organized the Real Women Unreal Jobs day for girls. The objectives of this event were: having a positive impact on the media and community perceptions regarding women in the IT industry; positively impacting the number of girls entering IT studies; and positively impacting the number of women entering the IT industry (Bernhardt, 2001). The one-day event was broken into three sections. The morning sessions were aimed at girls in lower secondary school, afternoon sessions at senior secondary and first year university students, with later afternoon sessions for other university students. A total of 825 girls attended over the day. Sessions were conducted in lecture-style presentation format using female role models rather than the provision of hands-on practical sessions. The event was evaluated via a post event survey completed on the day. A resounding $91 \%$ of participants indicated that they received a positive feeling about careers in IT, with $92 \%$ noting a positive feeling about women in IT. This short term attitudinal change convinced the organizers that the day was "highly successful" (Bernhardt, 2001), although a number of "lessons learned" were suggested to improve future incarnations of the event.

In 2001, the Women are IT (Also abbreviated as WIT. It is loosely connected with Women in Information Technology Inc.) organization in the state of Victoria organized the Go Girl, Go For IT Expo for nearly 1200 secondary school girls and their teachers over two days at Monash University. The aim of the event was "to expand the career horizons of young women ... by showing them the range of career opportunities available for them in IT, with an ultimate aim to redress the gender imbalance in the IT industry" (Carbone \& Sheard, 2001, p. iv). A variety of high impact, exciting presentations were given by academics and women from industry, but once more no hands-on sessions were provided due to the logistics of dealing with such a large group of attendees. At the end of the day the girls exchanged a completed post-event survey for a show bag full of free gifts and information. Some 1192 useable questionnaires were completed by the girls and 69 from accompanying teachers. Analysis of these surveys indicated that the event had been an extremely informative and exciting experience for most of the participants (Carbone \& Sheard, 2001). Carbone and Sheard (2001) further reported that a significant finding from the data analysis was that after the event $84 \%$ of the girls stated that they would now consider a career in IT compared with only $52 \%$ prior to the event (based on self-reporting). Furthermore, $86 \%$ of the teachers indicated that they would recommend IT as a suitable career option for their female students.

Greater networking, collaboration, and sharing of information between WIT groups across Australia resulted in numerous larger scale events being conducted in the early years of this century (see Table 1). Each of these events was organized by a variety of independent groups (such as the Victorian ICT for Women Network, WIT (WA), WIT (Qld)) with no two events being exactly the same. Even when the event was run on consecutive days to enable more girls to attend, the two days were rarely identical due to the availability of speakers and resources. All of the events were evaluated by post-event surveys with lessons learnt made available to other groups. 
Table 1: Australian Large Scale Girls in Computing days 2000- 2008

\begin{tabular}{|c|c|c|c|c|}
\hline Year & Location (State) & Name & $\begin{array}{l}\text { Aimed at } \\
\text { Years }\end{array}$ & Attendance \\
\hline 2000 & $\begin{array}{l}\text { Clunies Ross Centre } \\
\text { (Queensland) }\end{array}$ & Real Women, Unreal Jobs & $\begin{array}{l}\text { 7-12, } \\
\text { Univ. }\end{array}$ & 825 girls \\
\hline 2001 & $\begin{array}{l}\text { Monash University } \\
\text { (Victoria) }\end{array}$ & Go Girl Go For IT & $7-12$ & $\begin{array}{l}1200 \text { girls } \\
69 \text { teachers }\end{array}$ \\
\hline 2002 & $\begin{array}{l}\text { Edith Cowan University } \\
\text { (Western Australia) }\end{array}$ & Go Girl Go For IT & $7-12$ & $\begin{array}{l}1100 \text { girls } \\
66 \text { teachers }\end{array}$ \\
\hline 2002 & $\begin{array}{l}\text { Clunies Ross Centre } \\
\text { (Queensland) }\end{array}$ & South East Queensland Role Model & $6-12$ & $400+$ girls \\
\hline 2003 & $\begin{array}{l}\text { Clunies Ross Centre } \\
\text { (Queensland) }\end{array}$ & Build the Future & $6-12$ & $400+$ girls \\
\hline 2004 & $\begin{array}{l}\text { University of Queensland } \\
\text { (Queensland) }\end{array}$ & $\begin{array}{l}\text { Pathways to Technology } \\
\text { (2 events) }\end{array}$ & $7-10$ & 1500 girls \\
\hline 2004 & $\begin{array}{l}\text { Murdoch University } \\
\text { (Western Australia) }\end{array}$ & Go Girl Go For IT & $8-12$ & $\begin{array}{l}1450 \text { girls } \\
68 \text { teachers }\end{array}$ \\
\hline 2005 & $\begin{array}{l}\text { Griffith University } \\
\text { (Queensland) }\end{array}$ & Technology Takes You Anywhere & $7-10$ & 1500 girls \\
\hline 2006 & $\begin{array}{l}\text { Murdoch University } \\
\text { (Western Australia) }\end{array}$ & Go Girl Go For IT & $9-12$ & $\begin{array}{l}1900 \text { girls } \\
79 \text { teachers }\end{array}$ \\
\hline 2006 & $\begin{array}{l}\text { Brisbane North Institute of } \\
\text { TAFE (Queensland) }\end{array}$ & Technology Takes You Anywhere & $6-12$ & $900+$ girls \\
\hline 2006 & $\begin{array}{l}\text { Deakin University } \\
\text { (Victoria) }\end{array}$ & Go Girl Go For IT & $8-12$ & $\begin{array}{l}1900 \text { girls } \\
178 \text { teachers }\end{array}$ \\
\hline 2007 & $\begin{array}{l}\text { University of Queensland } \\
\text { (Queensland) }\end{array}$ & $\begin{array}{l}\text { Technology Takes You Anywhere } \\
\text { (3 events) }\end{array}$ & $6-12$ & $900+$ girls \\
\hline 2008 & $\begin{array}{l}\text { Brisbane North Institute of } \\
\text { TAFE (Queensland) }\end{array}$ & $\begin{array}{l}\text { Technology Takes You Anywhere } \\
\text { (2 events) }\end{array}$ & $\begin{array}{c}5-7 \\
8-12 \\
\end{array}$ & $900+$ girls \\
\hline 2008 & $\begin{array}{l}\text { Deakin University } \\
\text { (Victoria) }\end{array}$ & Go Girl Go For IT & $8-12$ & $\begin{array}{l}1300+\text { girls } \\
100+\text { teachers }\end{array}$ \\
\hline
\end{tabular}

As well as these very large scale events, rural and regional events were also conducted in some states. During 2006, for example, a regional tour of Cairns, Townsville, Central Queensland and Wide Bay was conducted by WIT in Queensland. In each of these regions girls in Years 9 to 12 were introduced to technology and its opportunities through interactive presentations, hands-on workshops, and competitions. They also had the opportunity to talk to female role models, adding a more personalized connection to ignite student interest in IT careers.

\section{Success of Girls in Computing Days?}

The question has to be raised as to whether it is realistic to expect that girls would change their expectations and career plans after a positive one day experience. This had been noted in the literature relating to other taster days (Lindley, 1995); however, career decision-making research does conclude that this may in fact occur and is termed "happenstance" or "turning points" (Hodkinson \& Sparkes, 1997). These authors suggest that, indeed, students do make decisions based on short term experiences (p. 39). However another study conducted in New Zealand suggested that the timing of days is most important. If students are in their final year of schooling they are already "locked in" to their future career choices, and these days will have minimal impact (Gale, Andreae, Biddle, Brown, \& Tempero, 1997, p. 20). The New Zealand finding, it should be noted, is based on a very small sample and anecdotal reporting. Most of the research, however, from the programmes reported in the literature has not explored success apart from the initial impact of the day. 
One study was undertaken in 1996 to determine the longer term effects of the 1992 Girls in Computing day held at Victoria University. Thirty-six of the eighty-one Year 10 girls who participated in the 1992 event were interviewed. Of these girls, 29 had gone on to study a computing subject in Year 11, and 25 studied a final year (Year 12) computing subject, but only one girl went on to study computing at a tertiary level (see Table 2). Seventeen of the girls (47\%) indicated that the program had positively influenced their future degree and career choices. Nineteen of the girls (53\%) reported that they already had firm ideas before the program and hence were not greatly influenced by the day. Thirty-one of the girls had moved on to tertiary institutions with nearly $60 \%$ choosing Victoria University as the University of choice. Some girls indicated that they would have preferred to go to Victoria University but their chosen discipline was not available at this institution. These results beg the question of the value of the Girls in Computing day for encouraging more girls into IT over the experience of a general recruitment day for the individual university involved.

Table 2: Long term effect of 1992 Girls in Computing Day, Victoria University, Australia

\begin{tabular}{|l|c|c|}
\hline \multicolumn{2}{|c|}{ Choices made at Secondary school } & $\mathrm{n}=36$ \\
\hline Studied computing in Year 11 & 29 & $81 \%$ \\
\hline Studied computing in Year 12 & 25 & $69 \%$ \\
\hline \multicolumn{2}{|c|}{ Choices made at Tertiary level } & $\mathrm{n}=31$ \\
\hline Studied a computing degree & 1 & $3 \%$ \\
\hline Studied at Victoria University & 19 & $61 \%$ \\
\hline
\end{tabular}

With regard to the workshops held at Glasgow University in the late 1980s, Siann and Callaghan (2001, p. 88) suggest that while these workshops were "held up as exemplars to other universities," the impact on increasing the number of girls into computer science degrees "has been negligible" (Pearce, 1998, p.8 as cited in Siann \& Callaghan, 2001). If success is measured in tertiary enrolment numbers then these days had minimal impact.

Australia wide statistics indicated that over the period 1990 - 2000 the number of women studying computing degrees at higher education had increased in raw numbers. However, proportional participation of women fluctuated within the specializations of the discipline (see Figure 1), and men were increasingly attracted to these degree courses at a much greater rate than women. The graph indicates a marked decline in the participation of women in Information Systems (IS) yet in reality the actual number of women enrolled almost tripled (927 in 1990 to 2,599 in 2000), but male participation increased at a much greater rate (1,077 in 1990 to 5,625 in 2000). The proportional participation of women in Computer Science (CS) had declined by several percentage points, even though the number of women had more than doubled (1,084 in 1990 to 2,694 in 2000). This data is confounded by the inclusion of double-degree statistics since 1997, where both areas of study for a student with two majors are included, which may account for the slight upturn in percentages towards the end of the century. It should also be noted that demand generally for IT degrees by 2000 was very high due to the well published skill shortage as a result of Y2K. This was further exacerbated in Australia in particular because of the introduction of a Goods and Services Tax (GST) which necessitated many organisations having to reconfigure current databases and accounting systems to conform to the new government requirements to report GST revenue. This event created greater demand for IT specialists. 


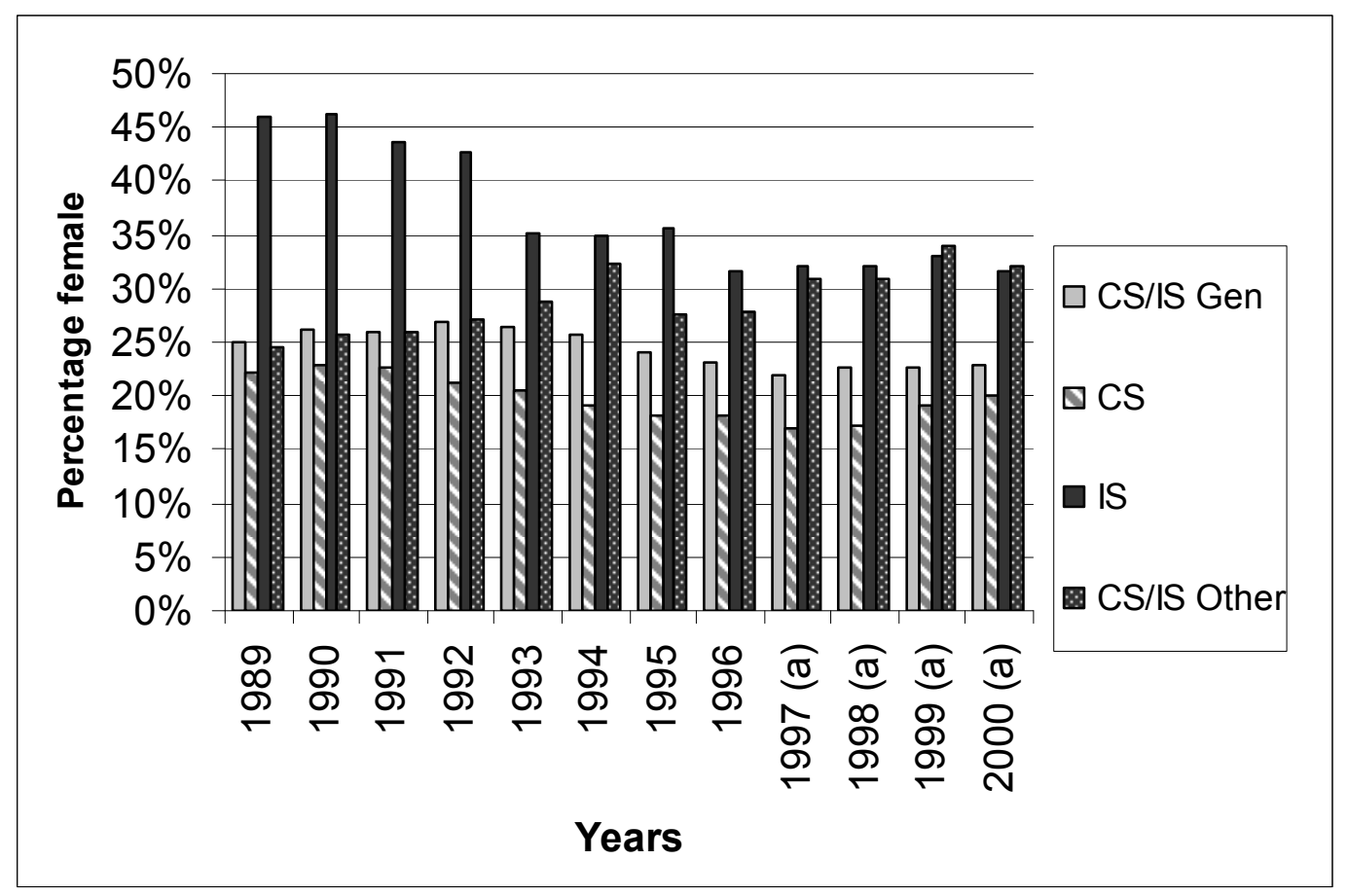

Figure 1: Proportional female enrolments within IT specialist areas. Figures from 1997 to 2000 (a) include double degrees

(Department of Education, Science and Training [DEST], 2002)

At this time the actual number of individual women attracted to IT degrees was improving; however, the proportional figures indicate a further decline. In 2000 the number of girls enrolling in tertiary computer degrees had dropped to $24.4 \%$ Australia wide (Lang \& Hede, 2004), down from $27.6 \%$ in 1991, and has never looked like it will reach the $40 \%$ target set by the Federal Government. These figures raised the question: Were the promotional days just not successful or would the number of women selecting IT degrees have been even less without the occurrence of these days? As the small scale uncoordinated projects implemented across the country did not seem to be having enough of an effect, it could be expected that the larger programmes implemented after 2000 may have had more of an impact on enrolment of women in IT degrees. This, however, has not happened (see Table 3). In fact in the $21^{\text {st }}$ century the total number of students, male or female, enrolled in any IT degree has been in decline (see Figure 2). From 2002 to 2007 there has been a staggering decline of $41 \%$. Australia-wide the enrollment by female students decreased by $56 \%$ and by male students $36 \%$. It is not known what effect external influences, such as the dot.com crash reported in 2000 or frequent media articles on outsourcing and off-shoring, have had on the perceptions and aspirations of the girls who had attended Girls in Computing day events, but it is apparent that there has not been a subsequent increase in proportional representation of women in IT degrees at university or at secondary school. In Victoria, for example, the total number of enrolments in IT units at VCE has declined from over 40,000 in 2000 to approximately 35,000 in 2004. The number of enrolments of girls in these units has more than halved in the same time period, from over 32,000 to less than 14,000 (Lang, Lewis, \& McKay, 2006). 
Table 3: Students, Australia wide, enrolled in undergraduate Information Technology degrees (DEST, 2008)

\begin{tabular}{|c|r|r|r|r|r|r|r|}
\hline & $\mathbf{2 0 0 1}$ & $\mathbf{2 0 0 2}$ & $\mathbf{2 0 0 3}$ & $\mathbf{2 0 0 4}$ & $\mathbf{2 0 0 5}$ & $\mathbf{2 0 0 6}$ & $\mathbf{2 0 0 7}$ \\
\hline Females & 11566 & 13809 & 13170 & 11281 & 8911 & 7162 & 6101 \\
\hline Total Persons & 45566 & 56654 & 55906 & 51085 & 43124 & 37267 & 33381 \\
\hline \% Females & $\mathbf{2 5 . 3 8 \%}$ & $\mathbf{2 4 . 3 7 \%}$ & $\mathbf{2 3 . 5 6 \%}$ & $\mathbf{2 2 . 0 8 \%}$ & $\mathbf{2 0 . 6 6 \%}$ & $\mathbf{1 9 . 2 2 \%}$ & $\mathbf{1 8 . 2 8 \%}$ \\
\hline
\end{tabular}

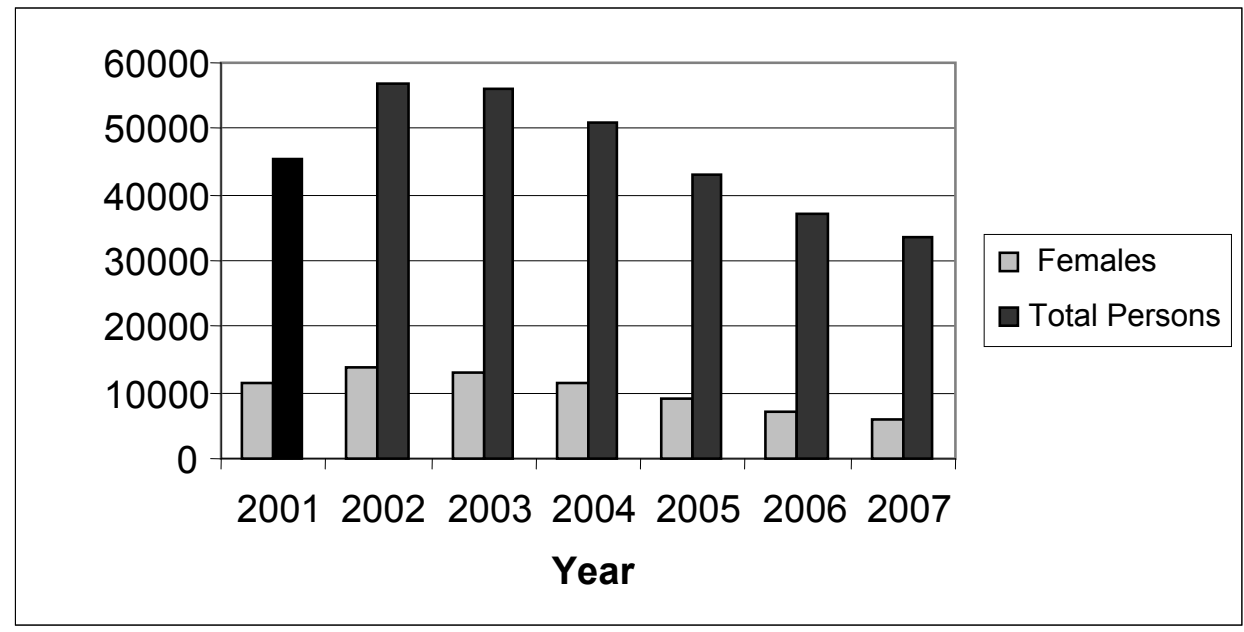

Figure 2: Students, Australia wide, enrolled in undergraduate Information Technology degrees (DEST, 2008)

\section{Costs and Benefits of Large Events}

Despite the 2001 large scale event held in Victoria appearing to have little impact on IT enrolment statistics at senior secondary school or university, a similar large scale event was held in 2006. The following sections describe this Go Girl Go for IT event and the benefits and costs associated with its implementation. In 2006 the Victorian event was organized by the Victorian ICT for Women Network. The event was held over two days, with a similar program operating on each day (see Table 4). It is estimated that 1900 girls and their teachers attended over the two days.

Table 4: Summary of the 2006 Go Girl Go for IT event

\begin{tabular}{|l|l|}
\hline Time & Activity \\
\hline $9.00-9.55$ & Trade show \\
\hline $10.00-12.00$ & Four concurrent sessions, each had presentations from four speakers \\
\hline $12.00-12.55$ & Trade show / Fashion parade of work wear / Rock band \\
\hline $1.00-3.00$ & Four concurrent sessions, each had presentations from four speakers \\
\hline
\end{tabular}

The trade show enabled the girls to speak with individual role models, seek information from recruitment groups (from sponsoring organizations), and participate in a fact finding treasure hunt.

The event built on previous events and was evaluated by detailed (anonymous) student and teacher surveys. The student survey contained questions to gather demographic information from the girls (such as current school attending, year level, and current usage of computers). Questions relating to preferred presentations were asked as well as questions to measure students' interest in, and perceptions of, computing as a career. There were 1668 valid responses to the student 
survey. The teacher survey was completed by 118 teachers and contained questions related to the teachers' interest in computing, their discipline area, their perspective on the organization and management of the event, the facilities and finally the quality and content of the presentations.

Results from the surveys indicate that the event was a positive experience for students and that it changed their perceptions of a computing career. For example, Carbone and Sheard (2006) report that there was a "strong consensus [from the participants] that the event was worthwhile, extremely informative and an exciting experience." After the event $63 \%$ of the girls stated that they would consider a career in computing, with only $34 \%$ having considered such a career prior to the event. In addition $90 \%$ of the girls reported that the event gave them a positive feeling about computing. Over half of the girls (56\%) were interested enough to claim they would investigate more about computing and $57 \%$ would now consider selecting a computing subject at school.

Further analysis of these post-event surveys and of the event itself indicates the following tangible and intangible benefits and costs.

\section{Benefits}

\section{The students}

The students were asked to explain one thing they had learnt from attending the sessions. Almost all the students indicated that they had learnt something new with five major themes emerging from their responses:

1. IT Skills and technology

2. Variety and opportunities in IT careers

3. Different pathways to a career in IT

4. IT is not just for males and geeks

5. IT can be a rewarding and fulfilling career

Students gained accurate knowledge about the computing arena as well as exposure to a university campus. They were able to explore new possibilities, had an exciting and fun day and received a show-bag full of free promotional products and relevant information.

\section{The institution}

The University received positive exposure in the media. Many of the attending girls had not been on a university campus before and were impressed with the university.

\section{The volunteers and the industry}

Over 150 professional women (and a few men) volunteered their time, energy, passion, and expertise. The volunteers developed new and strengthened existing networks and gained personal satisfaction as a result of being part of such a successful event. The industry benefited by the greater awareness of the issue by the general public due to publicity in newspapers and magazines. The involvement of government representatives also heightened awareness of the importance of the issue to students as well as accompanying teachers.

\section{Costs}

\section{The students}

Sponsorship obtained enabled the event to be free for the girls. In many instances the bus transport was also partly or fully subsidized. The girls missed a normal day of school which may be 
seen as an advantage by some, but a disadvantage by others. Some girls were 'forced' to come as it was a compulsory school excursion (for example the entire Year 10 level came from one girls' school). Other schools only allowed girls that had an interest to attend and, therefore, brought a smaller group of girls. This meant that some girls were already interested and others were not likely to become interested, no matter what was on offer.

For some of the country girls, travel to the event required a four to five hour bus trip each way. The schools had normal programmes disrupted, needed to organize parental permission for each student, and in some instances required replacement teachers for the day.

\section{The institution}

The cost to the University included the use of many facilities; the staff time in helping to organize and run the event; extra costs associated with cleaning, rubbish removal, security; disruption to the university community with the lunchtime band, non availability of rooms, traffic congestion and overcrowded cafes.

\section{The volunteers and the industry}

Fifteen corporate sponsors donated AUD $\$ 90,000$ in cash and more than double that amount of inkind support. Presenters donated their time and enthusiasm. The event was a year in the planning. Some volunteers spent considerable time away from their paid work and some described feelings of exhaustion and 'burn-out' as a result.

\section{Large or Small Events: Does Size Matter?}

Intervention programmes such as the girls in computing days described here do have a degree of positive impact. Preliminary findings from a large-scale study in Queensland, for example, indicate girls who participated in these activities (large or small) were more positive about careers in IT, whether they undertook higher level IT subjects or not, and were more likely to consider enrolling in tertiary IT degrees (Anderson, Lankshear, Courtney, \& Timms, 2006).

In 2001 among the 1200 girls who participated in the Go Girl Go For IT event at Monash University was a group of twelve girls from a regional Catholic girls secondary school. Four of these twelve girls now work in the IT industry. Furthermore, two of the four girls participated in the organization of the 2006 Go Girl Go For IT event as they wanted to give other girls the opportunity that they had had in 2001. Consequently there can be no doubt that these types of days have influenced at least some girls to consider computing as a career and to complete computing degrees. However the question needs to be asked; how many girls need to be so influenced to consider these activities as a success?

On reflection the authors now question which events are indeed the best use of resources and time: smaller, more personalized events run regionally or state-wide activities. Alternatively, is it time to consider that neither strategy is successful enough on its own and that, therefore, other options need to be considered?

Gender in computing research indicates that girls are more likely than boys to be influenced by parents or a close personal contact in their career choices (Margolis \& Fisher, 2002). The career decision making literature strongly emphasizes the importance of situated cognition and individual schematic repertoires when choosing future careers or degrees. "In choosing any action an individual uses his/her own schematic repertoire. No-one can step outside their habitus, so decision-making can never be context-free" (Hodkinson \& Sparkes, 1997, p. 33). This seems to indicate that providing opportunities to meet with and talk to professional IT women, or role-models, will be more effective in smaller localized events than large-scale state-wide ones. Akbulut and 
Looney (2007) developed a multi-choice goal model after surveying 206 students in the US. They concluded that degree and career choice is affected by multi-faceted factors of self-efficacy, outcomes expectations, and interest. Their results would suggest that events that enable a smaller audience to make personal interaction with IT professionals and experience hands-on activities have greater potential to influence student aspirations than large events. However, smaller events result in reaching a smaller number of girls. Smaller events also have lesser drawing power for sponsorship, securing quality presenters, and gaining media exposure.

While the costs and benefits for each event will differ somewhat, a picture is emerging of the substantial costs associated with running these events. Does the size of the event matter? Is there greater impact from a larger event? Is the impact more significant at smaller events? After 20 plus years of such programmes the results are inconclusive. From the data gathered by past girls in computing day programmes it is impossible to know how many girls have actually been influenced enough by such days to go on and consider studying and enrolling in computing degrees. Short term impact has often been measured by "Did you have a good day?" type questionnaires rather then measuring any attitudinal change. The sustainability of the positive attitude has not been tested over a longer time period, for example, whether the positive attitude is retained for days, weeks, months or years. Longer term impacts have not been measured at all by many programmes due to difficulties with resources, privacy issues, consent, and the tracking of participants.

Further research is urgently required to help shed light on the situation. The goodwill of the many volunteers who provide these events can not be expected to last indefinitely and statistics indicate that the problem has only become worse. Since 2000 in Australia, boys are still attracted to IT degrees at almost three times the rate of girls, despite women now being almost equal in their computer use and application use (VTAC, 2005). This also raises the question, "Where would the women in computing numbers be if the intervention programmes had not been conducted?"

\section{Conclusion}

There are several paradoxes associated around these Girls into Computing days. The first revolves around size of the events and workload of those involved in organizing the events. These days are usually run by volunteers on top of their regular work, usually women in IT faculty, schools, and industry. For example, the Victoria University Girls in Computing days were discontinued after six years despite definite benefits for the University because the academics who voluntarily conducted the program were no longer convinced the program was having enough impact to outweigh the enormous time commitment required to ensure the program operated well and were "burnt-out" from the effort. The second paradox is that the minority gender in the discipline (women) is the predominant owner of the problem. The gender of the researchers investigating the issues regarding Women in IT is predominately female "indicating that this conversation is still rarely extending to the majority gender in the discipline" (Lang, 2007, p.217). This gender paradox complicates the evaluation of whether size matters in the construction of events to increase awareness around IT careers.

The issue of the lack of girls in the pipeline of computing education and then women in the computing industry is, indeed, a complex one and an issue that needs to be embraced by the majority gender of the profession. If intervention programmes are to contribute towards the solution they need to be better understood and, therefore, it is necessary that a stronger focus on evaluation is incorporated into all future events.

A more strategic view in how we measure and evaluate these 'taster' days needs to be adopted. Throughout the planning, design, and implementation of any girls in computing program the fol- 
lowing questions need to be asked: "What will a successful program look like?" and "How will we measure this?" Success in the short term may be a shift in a student's attitude or an improved knowledge of computing careers. Validated instruments need to be put in place that can measure these impacts rather than assessments which show just if the girls enjoyed the day. Success in the longer term may be that a participant had a positive attitude to computing, explored the possibility of undertaking a computing subject, sought more information about computing careers, or enrolled in a computing degree. Results of both the short and longer term impacts, as well as the context of the particular program, need to be gathered and shared.

A first step in this direction will be undertaken in 2009. It is anticipated that the 1900 participants in the 2006 Victorian Go Girls event will be surveyed to enable gathering of data regarding the longer term impacts of the event. Until we have conclusive evidence of what works well and what does not, both large and small events are still required as the issue of equity of outcomes in terms of women and computing is too important to ignore.

\section{Acknowledgments}

To the many volunteers, including members of WIT (Q1d), WIT (WA), WIT (Vic), Victorian ICT Network for Women and GIDGITS, without whose energy and passion these events could not happen - our sincere thanks.

\section{References}

Akbulut, A. Y., \& Looney, C. (2007). Inspiring student to pursue computing degrees. Communications of the ACM, 50(10), 67-71.

Anderson, N., Lankshear, C., Courtney, L., \& Timms, C. (2006). Girls and ICT Survey: Initial findings. Curriculum Leadership, 4(12). Accessed in June 2007 from http://cmslive.curriculum.edu.au/leader/vol4_no12,12704.html?issueID=10270

Bernhardt, S. (2001). WIT real women unreal jobs, Post event analysis report. Unpublished report.

Byrne, G., \& Staehr, L. (2005). Women in the Australian IT industry: Where are we now? Australian Journal of Information Systems, 13(1), 8-18.

Carbone, A., \& Sheard, J. (2001). Go Girl, Go For IT 2001 Expo: Analysis of student and teacher surveys. Unpublished report.

Carbone, A., \& Sheard, J. (2006). Go Girl, Go For IT 2006 Evaluation report. Unpublished report.

Craig, A., \& Fisher, J. (1996). The effectiveness of a one day introduction to information technology for year 10 girls. In L. Godfrey (Ed.), Proceedings of the Second Australasian and South Pacific Region GASAT Conference, University of Auckland, 12-19.

Craig, A., Fisher, J., Scollary, A., \& Singh, M. (1998). Closing the gap: Women education and information technology courses in Australia. Journal of Systems and Software, 40(1), 7-15.

Department of Education, Science and Training [DEST]. (2002). Statistical publications. Requested and purchased statistics RFI:02-557

Department of Education, Science and Training [DEST]. (2008). Selected Higher Education Statistics. Retrieved August 22, 2008, from http://www.dest.gov.au/sectors/higher education/publications resources/statistics/publications higher education_statistics_collections.htm\#studpubs

Doerschuk, P., Liu, J., \& Mann, J. (2007). Pilot summer camps in computing for middle school girls: From organization through assessment. Proceedings of the 12th SIGCSE conference ITiCSE '07, ACM

SIGCSE Bulletin, 39 (3). 
Fisher, J., Perry, M., Scollary, A., Singh, M., Watson, D., \& Vale, C. (1992). Women in computing. Occasional Paper, Victoria University, Department of Computing.

Gale, A., Andreae, P., Biddle, R., Brown, J., \& Tempero, E. (1997). Computer science retention and recruitment at VUW. Proceedings of the Fourth Australian Women in Computing University of Melbourne, Australia, University of Melbourne.

Gibson, R., \& Hartnett, J. (1993). Escaping the stereotype: Is it harder for girls? In J. Fisher (Ed.), Networking for the Nineties- The Second Women in Computing Conference, Victoria University of Technology, Melbourne, 21-32.

Hodkinson, P., \& Sparkes, A. C. (1997). Careership: A sociological theory of career decision making. British Journal of Sociology of Education, 18(1), 29-44.

Hossler, D., Schmit, J., \& Vesper, N. (1999). Going to college: How social, economic, and educational factors influence the decisions students make. Baltimore, Maryland: The John Hopkins University Press.

Lang, C. (2007). Twenty-first century Australian women and IT: Exercising the power of choice. Computer Science Education, 17(3), 215-216.

Lang, C., \& Hede, T. (2004) Gender \& IT: Do stereotypes persist? Human perspectives in the Internet society: Culture, psychology and gender. Cadiz, Spain: WIT Press

Lang, C., Lewis, S., \& McKay, J. (2006). Declining popularity increases lack of diversity in the ICT discipline: Extending the discourse of the discipline. Adelaide: ACIS.

Lindley, J. (1995) Taster Days: Sweet or Sour? Gender Matters, Winter, National Centre for Women: Employment, Education and Training, Swinburne University, 2.

Margolis, J., \& Fisher, A. (2002). Unlocking the clubhouse: Women in computing. Cambridge, Massachusetts, USA: The MIT Press.

Moses, L., Isles, R., Grundy, F., Bernstein, D., Clarke, V., \& Teague, J. (1994). Too few women! Too few minorities! What can we do? Proceedings of the Twenty-fifth SIGCSE Symposium on Computer Science Education SIGCSE '94, ACM SIGCSE Bulletin, 26 (1).

Siann, G., \& Callaghan, M. (2001). Choices and barriers: Factors influencing women's choice of higher education in science, engineering and technology. Journal of Further and Higher Education, 25(1), 85-95.

Sivilotti, P., \& Demirbas, M. (2003). Introducing middle school girls to fault tolerant computing. Proceedings of the 34th SIGCSE Technical Symposium on Computer Science Education SIGCSE '03, ACM SIGCSE Bulletin, 35(1).

Vale, C. (1992). Girls into technology day - Computing. Paper presented at the Symposium on Women in Computing, University of Tasmania at Launceston.

Virginia Tech. (2007). Association of Women in Computing -- Women in Computing Day. Retrieved October 2007 from http://www.awc.org.vt.edu/wicd.html

VTAC. (2005). Analysis of applications, offers, enrolments and deferments by school type 2002-2003. Section G School Data. Retrieved 23 November 2005 from http://www.vtac.edu.au/pdfystats/20022003/section-G.pdf

Watt, H. (1988). Women into Computing Workshops. In B. Segal, D. Tregear, \& P. Newton (Eds.), First National Conference Women into Computing, Lancaster, pp. 112-114. 


\section{Biographies}

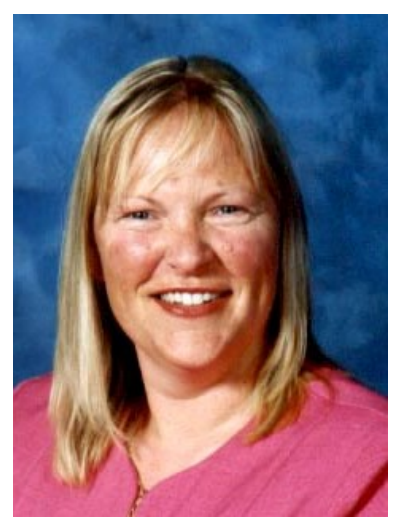

Dr Annemieke Craig is a Senior Lecturer in the School of Information Systems at Deakin University, Australia. Annemieke has been involved in numerous research investigations concerning the attraction, retention and advancement of women in the ICT area. Annemieke's research interests also include issues related to online learning and website usability.

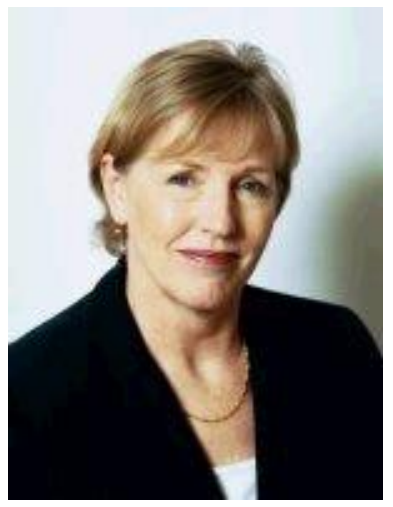

Dr Catherine Lang is a Senior Lecturer in the Faculty of Information and Comunication Technology at Swinburne University, Melbourne. She has been researching women in IT since 1996 and completed a research Masters degree analysing cross-cultural differences in female IT enrolments in 1999. In 2007 she completed her PhD at the University of Melbourne investigating factors that influence student course and career-choice with a particular focus on girls and IT. Catherine is the ACM-W Australian Ambassador for Women in Computing as well as a founding member and Deputy Chair of Victorian ICT for Women Network.

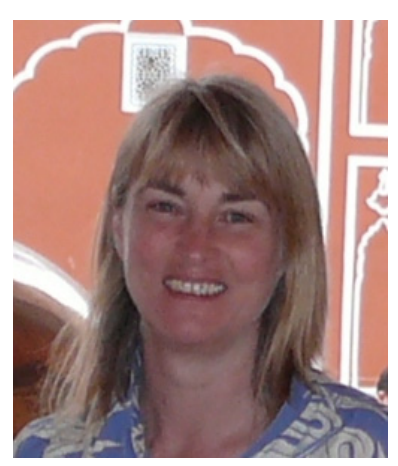

Dr Julie Fisher is an Associate Professor in the Faculty of IT at Monash University, Australia. She has worked and conducted research in the information systems field for the last 17 years. Her work has focused on usability, particularly in relation to systems development, gender and IT and more recently she has developed an interest in outsourcing. Her other research interests include IT education and curriculum development and information systems development. She has also led projects in usability testing of small business web sites, mobile implementation in a hospital ward and development of health portals. 